\title{
Ioknowledgments
}

This book came to be through the help and kindness of very many people. I'm grateful to Temple University for awarding me a research and study leave to work on this project, as well as two travel grants-in-aid. I have been especially fortunate to have the support and encouragement of my friend and boss, Department of Journalism Chair Andrew Mendelson. I appreciate the research assistance of Temple doctoral students Eliza Jacobs, Amanda Scheiner McClain, and Siobahn Stiles as well as the many insights I have gained from other graduate students who have taken my Media and Social Memory class over the years. Librarian Rebecca Traub at the Temple Harrisburg campus also was a key research ally on this project.

Over the three and a half years I've been working on this book, I have received dozens of suggestions on places I should see, and many friends and colleagues have steadily sent me articles and links of interest. Denise Graveline was always on the lookout for industrial heritage news; Matthew Lombard, who shares my enthusiasm for trains, directed me to numerous articles, websites, and events; and Rick Popp offered valuable insights as he pursued his own study of tourism history.

Other academic colleagues provided advice along the way. Even before I knew I was working on a book, Kurt Bell, archivist at the Railroad Museum of Pennsylvania, accompanied me on the Road of Anthracite in the summer of 2004 when I was a Pennsylvania Historical and Museum Commission (PHMC) scholar in residence, an opportunity that was made possible by PHMC historian Linda Shopes, who directed that program. Robert Weible, former director of public history for the PHMC and the State Museum of Pennsylvania, now the state historian and chief history curator of the New York State Museum, patiently listened to me try to articulate this idea in its early stages and provided valuable suggestions. Simon Bronner, Distinguished Professor of Folklore and American Studies at Penn State Harrisburg, has opened many doors for me in the study of Pennsylvania public history and took an active interest in this project. I received valuable feedback from other scholars when I presented parts of 
this research at conferences of the Pennsylvania Historical Association and the Mid-Atlantic American Studies Association.

A large cast of public history and tourism professionals contributed to this book, sharing their time and expertise with me by answering my interview questions in person, by telephone, by e-mail, or by letter. I would like to thank them here (realizing that some of their titles or jobs may have since changed), in alphabetical order: Christopher Barkley, director, Windber Coal Heritage Center; Brenda Barrett, director, Bureau of Recreation and Conservation, Pennsylvania Department of Conservation and Natural Resources (DCNR); Marilyn Black, vice president for Heritage Development, Oil Region Alliance of Business, Industry, and Tourism; Anita Blackaby, former PHMC director of special projects and former director of the State Museum of Pennsylvania (now director of The House of the Seven Gables in Salem, Massachusetts); Richard Burkert, executive director, Johnstown Area Heritage Association; August Carlino, executive director, Rivers of Steel Heritage Area; Sandra Carowick, former director, Quiet Valley Living Historical Farm; Terri Dennison, executive director, PA Route 6 Heritage Corridor; Eugene DiOrio, vice president and director, and Scott Huston, president, Graystone Society (Coatesville) and the proposed National Iron and Steel Heritage Museum; Janis (Jan) Dofner, communications director, Rivers of Steel Heritage Area; Steve Donches, former vice president of Bethlehem Steel and current executive director of the proposed National $\mathrm{Mu}$ seum of Industrial History; David Dunn, former director, Railroad Museum of Pennsylvania; Harold ("Kip") Hagan, superintendent, Steamtown National Historic Site; Olga Herbert, executive director, Lincoln Highway Heritage Corridor; Donna Holdorf, executive director, National Road Heritage Corridor; Sarah Hopkins, chief, Division of Environmental Education, Pennsylvania DCNR; Dan Ingram, curator, Johnstown Flood Museum; Chester Kulesa, historic site administrator, Pennsylvania Anthracite Heritage Museum and Scranton Iron Furnaces; Andy Masich, executive president, CEO, and director of John Heinz Regional History Center; Steve Miller, former director, Landis Valley Museum, and current director, Bureau of Historic Sites and Museums, PHMC; Dan Perry, chief operating officer, Lackawanna Heritage Valley Authority; Mark Platts, president, Lancaster-York Heritage Region (now Susquehanna Gateway Heritage Area); Norma Ryan, managing director, Brownsville Area Revitalization Corporation; Allen Sachse, executive director, Delaware and Lehigh Valley National Heritage Corridor; Edie Shean-Hammond, superintendent, Hopewell Iron Furnace National Historic Site; Lenwood Sloan, director of cultural and heritage tourism, Pennsylvania Tourism Office; Steve 
Somers, director, Cornwall Iron Furnace; Phil Swank, executive director, Endless Mountains Heritage Region; Kenneth Wolensky, historian, Bureau for Historic Preservation, PHMC; Barbara Zolli, director, Drake Well Museum; and Kurt Zwikl, executive director, Schuylkill River Heritage Area. Other public history and tourism professionals who helped me with this research include $\mathrm{Pa}$ mela Seighman, curator, Coal and Coke Heritage Center; Kirsten Stauffer, projects and outreach director, Lancaster-York Heritage Region; and Janet Wall, vice president for communications, Lancaster County Visitors Bureau.

I also would like to thank museum, site, park, and event directors and staffers whom I met on site during my travels and who spoke with me then in person or later by e-mail. They include Lori Arnold and Karen Popernack at the Quecreek rescue site; Carol Blair at the Petersburg Toll House on the National Road; Paul Fagley, environmental education specialist at Greenwood Furnace State Park; Raymond Grabowski Jr., president, Lake Shore Railway Historical Society (and my guide there, Jim); Sis Hause of the Danville Iron Heritage Festival; Glenn Kerr and Ted Ott at the Seldom Seen Mine; Nancy Kingsley of the Pumping Jack Museum and Oil Heritage Region Visitors Center; Ed Pany of the Atlas Cement Museum; Dan Rapak of the Harris Tower Restoration; Al Smith of the New Freedom Railroad Station; my mother's good friend Edith Umholtz at the Williamstown Historical Society; and Cindy Wooden of the Center for Anti-Slavery Studies.

I am grateful to my editor at Penn State University Press, Eleanor Goodman, for believing in this idea, as well as for her patience in awaiting its fruition. I also appreciate the work of Steve Kress, Amanda Kirsten, Laura Reed-Morrisson, Patricia Mitchell, Jennifer Burton, and Jennifer Norton, as well as the close attention and incredibly helpful suggestions of the anonymous reviewers of the manuscript.

As I explain in the introduction, a number of roads led me to this topic, but I especially thank a fictional character from a century ago, a woman in white named Phoebe Snow, for getting me started. Today she is only a ghost in a film about railroad heritage, but once she connected the two great industries in which my grandparents and great-grandparents worked. They are the other ghosts in this book. It is because they were coal miners and railroaders that I grew up in Pennsylvania. Despite its academic nature, this book has been, for me, a labor of love, a personal as well as professional-and a literal as well as philosophical-journey through my home state. To paraphrase the dedication inscription on one memorial to coal miners in the anthracite region, I owe Pennsylvania much. 


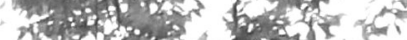

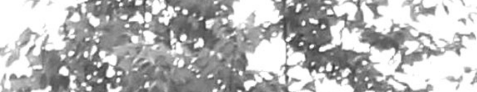

1. 025

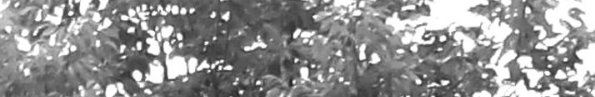

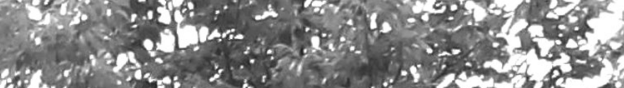

(1.2.

8

. 45.

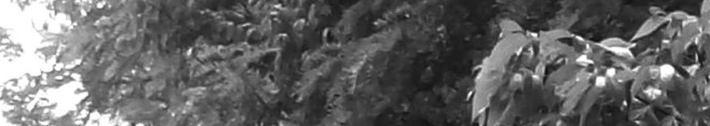

tos.

$$
\text { to: } 162 \text { is }
$$

\section{Naticunal Kngister}

1889

8

Mistoric District

年

Proud to bea Part of the

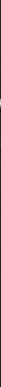

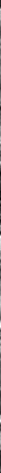

